\title{
Population structure of North Pacific humpback whales on their feeding grounds revealed by stable carbon and nitrogen isotope ratios
}

\author{
Briana H. Witteveen ${ }^{1,2,4, *}$, Graham A. J. Worthy ${ }^{1,3}$, Kate M. Wynne ${ }^{2}$, James D. Roth ${ }^{1}$ \\ ${ }^{1}$ University of Central Florida, Department of Biology, 4000 Central Florida Boulevard, Orlando, Florida 32826, USA \\ ${ }^{2}$ University of Alaska Fairbanks, School of Fisheries and Ocean Sciences, 118 Trident Way, Kodiak, Alaska 99615, USA \\ ${ }^{3}$ Hubbs-SeaWorld Research Institute, 6295 Sea Harbor Drive, Orlando, Florida 32821, USA \\ ${ }^{4}$ Present address: University of Alaska Fairbanks, School of Fisheries and Ocean Sciences, 118 Trident Way, Kodiak,
} Alaska 99615, USA

\begin{abstract}
Humpback whales Megaptera novaeangliae in the North Pacific Ocean are a migratory species known to have a complex population structure on both feeding and breeding grounds. We described the structure of this population using stable isotope analysis of skin samples (n = 1105) collected from free-ranging North Pacific humpback whales from 10 sampling regions in 2004 and 2005. We detected significant quadratic relationships between latitude and both $\delta^{13} \mathrm{C}\left(\mathrm{R}^{2}=0.29\right)$ and $\delta^{15} \mathrm{~N}$ $\left(\mathrm{R}^{2}=0.23\right)$ as well as between longitude and $\delta^{13} \mathrm{C}\left(\mathrm{R}^{2}=0.43\right)$ and $\delta^{15} \mathrm{~N}\left(\mathrm{R}^{2}=0.16\right)$. A weak negative linear relationship was seen between increasing distance from shore and both $\delta^{13} \mathrm{C}\left(\mathrm{R}^{2}=0.05\right)$ and $\delta^{15} \mathrm{~N}\left(\mathrm{R}^{2}=0.02\right)$. Sampling regions were significantly different for both $\delta^{13} \mathrm{C}\left(\mathrm{ANOVA}, F_{9,1094}=136.4\right.$, $\mathrm{p}<0.001)$ and $\delta^{15} \mathrm{~N}\left(F_{9,1095}=71.5, \mathrm{p}<0.001\right)$. We performed classification tree analyses using $\delta^{13} \mathrm{C}$ and $\delta^{15} \mathrm{~N}$ as predictor variables to assign membership to sampling regions. Results of initial classification and ANOVAs supported combining the 10 sampling regions into 6 feeding groups. When applied to these feeding groups, the classification tree was able to predict $57 \%$ of group membership correctly, with accuracy rates for individual groups ranging from a low of $19 \%$ to a high of $78 \%$. These results indicate that stable isotope analysis can be used to distinguish unique feeding aggregations of humpback whales within the North Pacific Ocean. Ultimately, isotopic characteristics of these aggregations can be applied to animals sampled on breeding grounds to assign them to a feeding aggregation, enhancing the ability to describe habitat linkages and migration patterns of humpback whales.
\end{abstract}

KEY WORDS: Stable isotopes $\cdot$ Humpback whales $\cdot$ Population structure $\cdot$ North Pacific Ocean

\section{INTRODUCTION}

Humpback whales Megaptera novaeangliae undergo one of the longest migrations of any mammal. Humpback whales spend the summer months foraging in productive high-latitude waters before migrating to lower latitudes to breed and give birth. During migration and while on mating and calving grounds, these whales feed very little or not at all (Dawbin 1966, Lockyer 1981, Baraff et al. 1991, Laerm et al. 1997). As a result, humpback whale distribution includes seasonal use of 2 (or more) different habitats, creating diverse and complex habitat needs; one habitat must support extended bouts of foraging while the other must be suitable for mating and calving.

Within the North Pacific Ocean, humpback whales are known to breed in the waters off the coasts of Asia, Mexico, Central America and the Hawaiian Islands. After migrating from their breeding grounds, humpback whales segregate geographically into several discrete feeding aggregations, between which very little exchange occurs (Waite et al. 1999, Calambokidis et al. 
2001, Witteveen et al. 2004). This pattern of movements means that whales feeding at one location may include individuals from multiple breeding grounds, creating a very intricate population structure (Calambokidis et al. 1996, Waite et al. 1999). A consequence of this complexity, coupled with the inherent difficulty in studying pelagic marine mammals, is that many demographic parameters for humpback whales, such as population structure, habitat use and migration patterns, remain poorly described.

One step in unraveling the complexity of humpback whale life history and habitat use is to identify their foraging aggregations. Previous and on-going research show feeding aggregations in waters of southeast Alaska, the California and Oregon coasts, Kodiak Island and the Shumagin Islands (Straley 1994, Calambokidis et al. 1996, Baker et al. 1998, Waite et al. 1999, Calambokidis et al. 2001, Witteveen et al. 2004). Opportunistic sightings and historic whaling data suggest that additional feeding aggregations exist in other areas of the North Pacific Ocean, such as waters off the coasts of Russia and British Columbia, Canada, but a lack of dedicated research effort in these and other areas makes defining them difficult (Nishiwaki 1966, Ivashin \& Rovnin 1967, Zerbini et al. 2006).

Traditionally, efforts to define humpback whale feeding aggregations and migration routes have relied on mark-recapture techniques employing either identification photographs or genetic tissue assays (i.e. comparison of mtDNA or haplotypes). Both techniques are limited by the requirement that individuals be sampled at both habitats. Recently, the analysis of stable carbon and nitrogen isotope ratios have been used in the analysis of migratory populations, specifically for studying aspects of population structure and feeding ecology (Hobson 1999, Kelly 2000, Farmer et al. 2003). The isotopic signatures in the tissues of a consumer reflect the ratio of heavy to light isotopes in its foods.

Carbon stable isotope patterns result primarily from processes associated with photosynthesis, with changes in the ratio of heavy to light carbon isotopes $\left({ }^{13} \mathrm{C} /{ }^{12} \mathrm{C}\right)$ indicating sources of primary production. Marine systems are significantly enriched, or show a higher relative concentration, in ${ }^{13} \mathrm{C}$ compared with $\mathrm{C}_{3}$ terrestrial systems due to the slower diffusion of carbon dioxide in water and the use of bicarbonate as a carbon source (Boutton 1991). In addition, carbon stable isotope ratios in marine systems have shown both latitudinal and benthic-pelagic gradients, which may result from differential freshwater influx and lighter stable carbon ratio values of phytoplankton (Fry 1981, Rau et al. 1982, Hobson et al. 1994). While carbon is an excellent predictor of location, ratios of nitrogen stable isotopes $\left({ }^{15} \mathrm{~N} /{ }^{14} \mathrm{~N}\right)$ provide a measure of relative trophic position. Nitrogen stable isotope ratios become less negative, or more enriched, with increasing trophic position due to the preferential excretion of ${ }^{14} \mathrm{~N}$ in metabolic processes (Minagawa \& Wada 1984). Geographically distinct patterns in both ratios have been used to investigate the migration patterns and rearing habitats of a number of species including birds, salmon and sea turtles, as well as whales (Born et al. 2003, Kennedy et al. 2005, Baduini et al. 2006, Hobson 2006, Rocque et al. 2006, Caut et al. 2008). More recently, stable isotope analysis has been employed to classify migratory species by their feeding or breeding origins (e.g. Caccamise et al. 2000, Hebert \& Wassenaar 2005a,b, Wunder et al. 2005, Szymanski et al. 2007).

The objectives of the present study were: (1) to use variation in isotopic carbon and nitrogen signatures of North Pacific humpback whales to describe distinct feeding groups, and (2) to use classification tree analysis to develop a predictive model to assign individuals to their foraging origins based on observed variation. Patterns in stable isotope signatures described in this study should be retained during migration and the breeding season as the result of humpback whale fasting behavior. As such, the model could be used to assign feeding destinations of animals sampled only on the breeding grounds eliminating the need for resampling to confirm a migratory connection. Further, combining stable isotope analysis with other data sets, including photo-identification and genetic markers, will increase the power of these tools in understanding the population structure and dynamics of humpback whales in the North Pacific Ocean.

\section{MATERIALS AND METHODS}

Sample collection. Samples for isotopic analysis were collected from free-ranging humpback whales throughout all known feeding areas in the North Pacific basin as part of the Structure of Populations, Levels of Abundance and Status of Humpback whales (SPLASH) project. The SPLASH project was initiated in 2004 in an effort to collect photographs and tissue samples from humpback whales throughout their known range in the North Pacific basin. Effort was divided into 10 sampling regions based on areas of pre-existing research effort, availability of researchers, or historic whaling records. Sampling regions were California and Oregon (CAOR), Washington and southern British Columbia (WASBC), northern British Columbia (NBC), southeastern Alaska (SEAK), northern Gulf of Alaska (NGOA), western Gulf of Alaska (WGOA), eastern Aleutian Islands (EAI), western Aleutian Islands (WAI), Bering Sea (BER), and Russia (RUS) (Fig. 1). Sampling occurred between 17 May and 


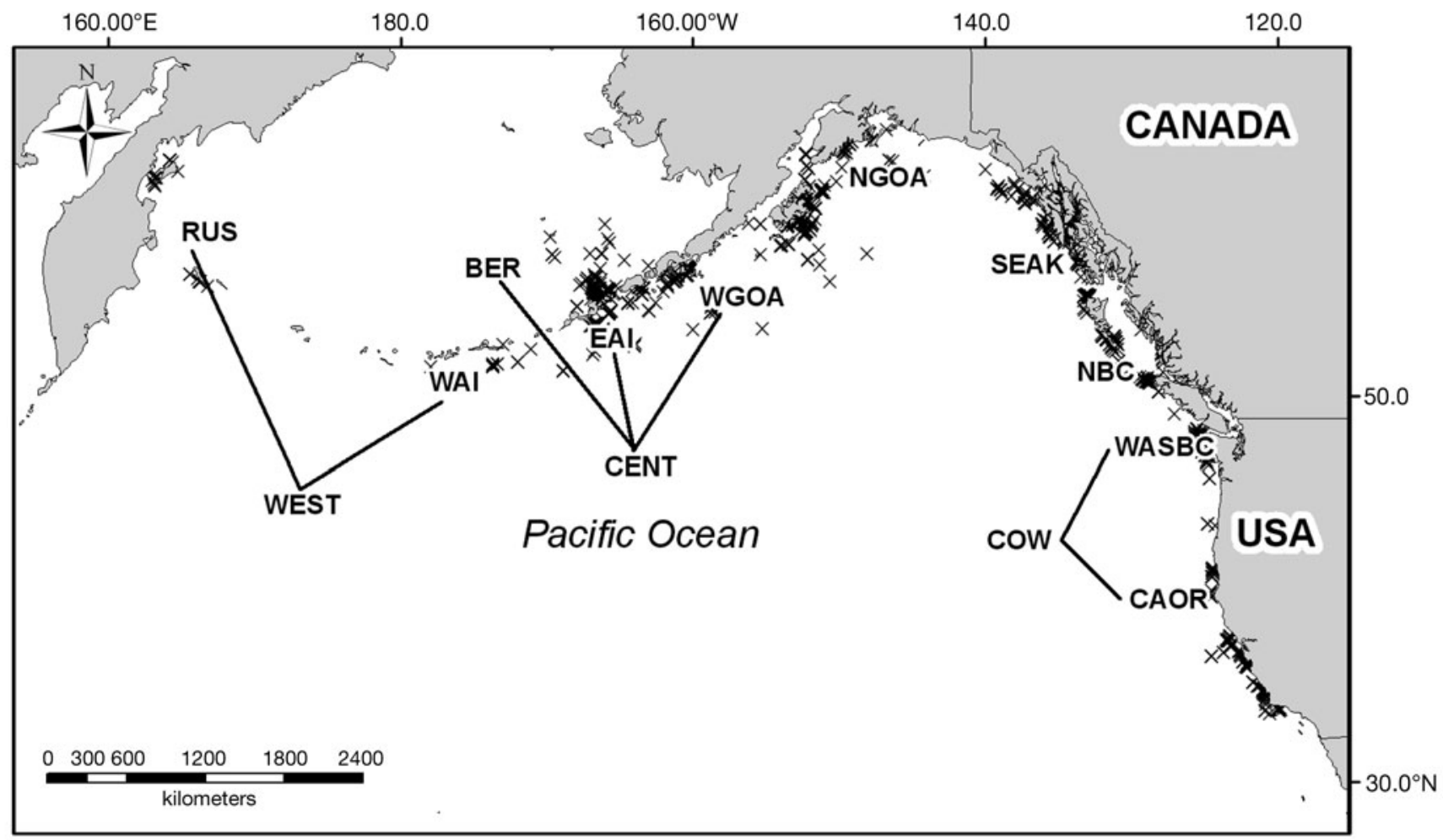

Fig. 1. The North Pacific Ocean showing the sampling locations $(X)$ and the 10 sampling regions of the SPLASH project. Lines drawn from sampling regions indicate consolidated feeding groups. Combined feeding groups (see 'Results: Classification') WEST: western region; CENT: central region; COW: California, Oregon, Washington and southern British Columbia. Further abbreviations in 'Materials and methods: Sample collection'

4 December 2004 and between 22 April and 4 December 2005 (Calambokidis et al. 2008). In total, 5604 samples were collected during SPLASH field efforts, of which 1121 were made available for stable isotope analysis. Samples collected from animals identified as calves, juveniles or dead (i.e. stranded) $(n=16)$ were immediately removed from analysis since it is not fully understood how samples from these categories may influence stable isotope ratios. An error during analysis of carbon meant one sample had a result for nitrogen only. Thus, a total of 1104 carbon and 1105 nitrogen samples were used for all analyses.

Samples were collected using a hollow-tipped biopsy dart fired by either a crossbow or modified 0.22 caliber rifle. Darts collected the entire skin layer and a portion of the blubber layer, but did not sample any muscle. The preferred sampling location was the dorsal flank, but samples were occasionally collected from the tail flukes. Skin that was sloughed following acrobatic displays (such as breaching and tail slapping) was also collected for analysis. At each sampling event, the date, location (latitude and longitude), group composition and general whale behavior were recorded. In addition, identification photographs of tail flukes of sampled animals were collected whenever possible.
As soon as possible after collection, samples were preserved by either freezing or storage in dimethyl sulfoxide (DMSO) or ethanol. Though freezing was preferred, it was not always possible at the more remote research locations and previous research has shown no significant difference when lipids are extracted from humpback whale and other cetacean skin when preserved in either DMSO or ethanol (Hobson et al. 1997, Todd et al. 1997, Marcoux et al. 2007).

Sample preparation and stable isotope analysis. A portion of skin from each sample (at least $10 \mathrm{mg}$ wet mass) was sliced into small pieces to increase surface area and then oven-dried for $24 \mathrm{~h}$, followed by lipid extraction using petroleum ether in an extractor (Soxhlet) for an additional $24 \mathrm{~h}$ (Dobush et al. 1985). Following lipid extraction, samples were again oven-dried at $60^{\circ} \mathrm{C}$ for 12 to $24 \mathrm{~h}$ to evaporate off any remaining petroleum ether.

Dried lipid-extracted samples were then ground to a powder to ensure homogenization. Aliquots (0.7 to $1.5 \mathrm{mg}$ ) of homogenized sample were sealed in $5 \times$ $9 \mathrm{~mm}$ tin capsules and then analyzed using an isotope ratio mass spectrometer (MAT Delta Plus XL, Finnigan) at the Stable Isotope/Soil Biology Laboratory of the University of Georgia, Institute of Ecology.

Stable isotope ratios were reported as per mille (\%o) using delta notation determined from the equation: 


$$
\delta X=\left[\left(\mathrm{R}_{\text {sample }} / \mathrm{R}_{\text {standard }}\right)-1\right] \times 1000
$$

where $X$ is ${ }^{15} \mathrm{~N}$ or ${ }^{13} \mathrm{C}$ and $\mathrm{R}$ is the corresponding ratio of ${ }^{15} \mathrm{~N} /{ }^{14} \mathrm{~N}$ or ${ }^{13} \mathrm{C} /{ }^{12} \mathrm{C}$. Standard reference materials were carbon from Pee Dee Belemnite and atmospheric nitrogen gas.

Quality assurance of stable isotope ratios was tested by running 1 known standard sample (bovine tissue) for each 12 unknown (humpback whale tissue) samples. Analytical errors for the bovine tissue $(n=204)$ were $\pm 0.1 \mathrm{SD}$ for $\delta^{13} \mathrm{C}$ and $\delta^{15} \mathrm{~N}$.

Statistical analysis. Data were tested for normality and homogeneity of variance using KolmogorovSmirnov (K-S) and Levene's test, respectively. Sex was determined for a subset of sampled animals $(\mathrm{n}=590)$ through genetic analysis (SPLASH unpubl. data). A preliminary ANOVA, controlling for year and sampling region, to determine whether sex influenced stable isotope ratios found no differences between males and females $\left(F_{1,554}=1.5, \mathrm{p}=0.215\right.$ for $\delta^{13} \mathrm{C}$ and $F_{1,555}=2.5, \mathrm{p}=0.128$ for $\left.\delta^{15} \mathrm{~N}\right)$. Thus, samples of known and unknown sex were pooled for the remainder of the analyses. Potential differences in the stable isotope ratios of animals that were sampled twice during the sample period were explored using paired sample $t$-tests. Twice-sampled animals were identified through photographs of the ventral surface of their tail flukes.

Relationships between $\delta^{13} \mathrm{C}$ and $\delta^{15} \mathrm{~N}$ and distance from shore, latitude and longitude were explored through polynomial regression analysis. Akaike's information criterion (AIC) was used to determine the best fitting regression (Burnham \& Anderson 2002). Distance from shore $(\mathrm{km})$ was calculated based on the distance from the sample location to the nearest coastline. Longitudes were standardized by using negative values to reflect the number of degrees west of the prime meridian.

Classification. Classification tree analysis was used to determine the ability of stable isotope ratios to classify humpback whales to feeding regions. Classification trees are grown by repeatedly splitting the data via algorithms that partition the data into mutually exclusive groups (Breiman et al. 1984, De'ath \& Fabricius 2000, StatSoft 2007).

Trees were constructed for analysis using sampling region as a categorical classification variable and $\delta^{13} \mathrm{C}$ and $\delta^{15} \mathrm{~N}$ as independent variables. The isotope ratios were tested separately and then together, creating 3 potential classification models. To avoid under- or overfitting the data, a single optimal tree in each model was selected as the simplest tree (smallest number of splits) with the highest predictive accuracy following methods developed by Breiman et al. (1984). The 3 optimal trees were then compared and the tree with the greatest explanatory power was selected as the best overall model for classification to sampling region. Following selection, the accuracy of the final model was assessed using cross-validation where one-third of the sample was withheld during initial analysis (see Hebert \& Wassenaar 2005a). The withheld data were then reclassified using the resultant model. This process was repeated 3 times. The final accuracy of the classification tree is taken as the combination of the 3 cross-validation applications. Finally, some sampling regions were combined to form isotopically similar feeding groups based on misclassification rates and geographic considerations. These feeding groups were then entered as the classification variables and analyzed with the optimal classification tree.

All statistics were conducted within SPSS 15.0 or JMP 7.0 for Windows with a critical value of $\alpha=0.05$ for all analyses (Moran 2003). Values presented are mean $\pm \mathrm{SE}$.

\section{RESULTS}

Regional means for $\delta^{13} \mathrm{C}$ ranged from a minimum of $-18.8 \pm 0.12$ from WAI to a maximum of $-16.3 \pm 0.05$ from CAOR (Table 1). For $\delta^{15} \mathrm{~N}$, the minimum regional mean was from WAI $(11.4 \pm 0.25)$ and the maximum regional mean was from CAOR $(14.7 \pm 0.09$; Table 1$)$. $\mathrm{K}-\mathrm{S}$ tests of normality were significant for $\delta^{13} \mathrm{C}(\mathrm{K}-\mathrm{S}=$ 0.033, $\mathrm{p}=0.006)$ and $\delta^{15} \mathrm{~N}(\mathrm{~K}-\mathrm{S}=0.030, \mathrm{p}=0.019)$. However, data were treated as normal due to a number of factors: transformations failed to improve non-normal data, the K-S test can often give significant results with respect to large sample sizes, and visual inspection of histograms and normal quantile-quantile (Q-Q) plots indicated normality (Field 2005).

Results of ANOVAs showed sampling regions differed significantly with respect to $\delta^{13} \mathrm{C}\left(F_{9,1094}=136.4\right.$, $\mathrm{p}<0.001)$ and $\delta^{15} \mathrm{~N}\left(F_{9,1095}=71.5, \mathrm{p}<0.001\right)$. Tukey's post-hoc tests grouped $\delta^{13} \mathrm{C}$ into 5 homogeneous subsets and $\delta^{15} \mathrm{~N}$ into 7 (Table 1 ).

\section{Geographic variability}

The isotope $\delta^{13} \mathrm{C}$ varied quadratically with latitude $\left(F_{2,1101}=225.4, \mathrm{r}^{2}=0.29, \mathrm{p}<0.001\right)$ and longitude $\left(F_{2,1101}=408.9, \mathrm{r}^{2}=0.43, \mathrm{p}<0.001\right) ; \Delta$ AIC of linear and cubic relationships were $>2$, indicating poorer fit than the quadratic regression (Burnham \& Anderson 2002). The relationship between $\delta^{13} \mathrm{C}$ and distance was equally well explained by linear, quadratic and cubic models (all AIC values were within 2), so the linear regression was selected as the most parsimonious, 
Table 1. Sample size, number of known females and males, and mean $\pm \mathrm{SE} \delta^{13} \mathrm{C}$ and $\delta^{15} \mathrm{~N}$ values for each of 10 sampling regions sampled as a part of the SPLASH project (parentheses: region minima, maxima). Letters in common next to region names indicate regions with similar $\delta^{13} \mathrm{C}$, while Roman numerals in common indicate $\delta^{15} \mathrm{~N}$ groupings. Abbreviations defined in 'Materials and methods: Sample collection'

\begin{tabular}{|lrcccc}
\hline Region & $\mathrm{N}$ & Females & Males & $\delta^{13} \mathrm{C}(\%)$ & $\delta^{15} \mathrm{~N}(\%)$ \\
\hline RUS b; ii, iii, iv & 67 & 37 & 25 & $-17.7 \pm 0.1(-19.5,-15.9)$ & $12.5 \pm 0.2(8.6,16.1)$ \\
BER a; ii, iii & 122 & 56 & 50 & $-18.5 \pm 0.0(-19.6,-15.9)$ & $12.4 \pm 0.1(7.4,15.7)$ \\
WAI a; i & 14 & 5 & 7 & $-18.8 \pm 0.1(-19.5,-18.1)$ & $11.4 \pm 0.3(10.1,13.4)$ \\
EAI a; ii & 56 & 24 & 26 & $-18.5 \pm 0.1(-19.6,-17.5)$ & $12.1 \pm 0.2(9.1,14.9)$ \\
WGOA a; vi vi & 104 & 39 & 27 & $-18.5 \pm 0.1(-23.0,-15.8)$ & $13.1 \pm 0.1(11.3,15.3)$ \\
NGOA b; vi & 199 & 47 & 44 & $-17.6 \pm 0.1(-20.2,-15.9)$ & $13.6 \pm 0.1(8.8,16.2)$ \\
SEAK c; iii, iv, v & 227 & 23 & 5 & $-17.2 \pm 0.1(-21.2,-15.4)$ & $12.7 \pm 0.1(7.8,15.1)$ \\
NBC b; iv, v & 135 & 1 & 3 & $-17.7 \pm 0.1(-20.0,-15.9)$ & $13.0 \pm 0.1(10.6,15.8)$ \\
WASBC d; vii & 53 & 17 & 29 & $-16.8 \pm 0.1(-18.8,-15.9)$ & $14.6 \pm 0.1(11.2,15.9)$ \\
CAOR e; vii & 128 & 55 & 70 & $-16.3 \pm 0.1(-17.9,-15.2)$ & $14.7 \pm 0.1(11.8,16.6)$ \\
Total & 1105 & 304 & 286 & $-17.6 \pm 0.0$ & $13.2 \pm 0.0$ \\
\hline
\end{tabular}

although the relationship was weak $\left(F_{1,1102}=52.3, \mathrm{r}^{2}=\right.$ 0.05, p $<0.001$; Fig. 2). Model selections using $\delta^{15} \mathrm{~N}$ were similar; $\delta^{15} \mathrm{~N}$ varied quadratically with latitude $\left(F_{2,1102}=164.7, \mathrm{r}^{2}=0.23, \mathrm{p}<0.001\right)$ and longitude $\left(F_{2,1102}=106.4, \mathrm{r}^{2}=0.16, \mathrm{p}<0.001\right)$ and was linearly related (but weakly) to distance from shore $\left(F_{1,1103}=\right.$ 27.1, $\mathrm{r}^{2}=0.02, \mathrm{p}<0.001$; Fig. 2).

\section{Individual variation}

A total of 42 animals were sampled twice during the study period; 35 were sampled within the same year while the remaining 7 were sampled in both 2004 and 2005. The mean values of $\delta^{13} \mathrm{C}$ and $\delta^{15} \mathrm{~N}$ for animals sampled twice within the same year were not significantly different from one another $\left(t_{34}=-0.12, \mathrm{p}=0.908\right.$ for $\delta^{13} \mathrm{C}$ and $t_{34}=-0.24, \mathrm{p}=0.809$ for $\left.\delta^{15} \mathrm{~N}\right)$. Similarly, no significant difference between means of $\delta^{13} \mathrm{C}\left(t_{6}=1.33\right.$, $\mathrm{p}=0.233)$ or $\delta^{15} \mathrm{~N}\left(t_{6}=1.39, \mathrm{p}=0.214\right)$ were found for animals sampled in both 2004 and 2005. However, differences in the mean isotopic signatures of animals sampled in different sampling regions within the same year $(n=3)$ were significant $\left(t_{2}=4.64, \mathrm{p}=0.043\right.$ for $\delta^{13} \mathrm{C}$ and $t_{2}=6.74, \mathrm{p}=0.021$ for $\left.\delta^{15} \mathrm{~N}\right)$.

\section{Classification}

The accuracy of the 3 classification models, shown by the percent of correct assignment to sampling region, was highest for the model that used both ratios as predictors (44.8\% correctly classified), followed by the $\delta^{13} \mathrm{C}$ only model $(37.9 \%)$ and $\delta^{15} \mathrm{~N}$ only model $(31.5 \%)$. The pattern was similar with respect to the explanatory power, with the dual isotope model show- ing the highest power $\left(\mathrm{R}^{2}=0.32\right)$, followed by $\delta^{13} \mathrm{C}$ $\left(R^{2}=0.23\right)$ and $\delta^{15} \mathrm{~N}$ with the smallest $\left(\mathrm{R}^{2}=0.14\right)$. Thus, the optimal tree from the model using both isotope ratios was selected as best.

The cross-validated optimal tree model correctly predicted sampling region for $45 \%$ of the samples. The model was able to correctly predict sampling region $>50 \%$ of the time for SEAK (64\%), BER (63\%), CAOR (54\%) and NGOA (54\%) (Table 2). The number of correct classifications for the remaining regions fell below $50 \%$. Regions often showed a majority of misclassifications to a single adjacent region. WASBC samples were most frequently assigned to CAOR (23\%), EAI to BER (61\%), and WAI to RUS (57\%) (Table 2, Fig. 1). Based on initial classification and results of ANOVA, the original 10 samples regions were combined to form 6 feeding groups. WASBC was combined with CAOR to form COW, and WGOA, EAI and BER were combined to form CENT. Finally, WAI was combined with RUS to form WEST. NBC was not combined with any other sampling region due to the wide distribution of misclassified samples from this region.

When applied to new feeding groups, results from the classification tree improved (Fig. 3). The explanatory power of the model increased to 0.37 and accuracy to $57 \%$ after cross-validation. The highest rates of accurate classification were in COW (78\%), SEAK (66\%) and CENT (77\%) (Table 3). Misclassification rates for NBC were high ( $81 \%$ misclassified) and were again distributed among several feeding groups. The majority of misclassifications for WEST were assigned to SEAK (32\%; Table 3 ). The accuracy of the model for NGOA was reduced from 54 to $33 \%$, with erroneous classifications attributed to both CENT (25\%) and SEAK (24\%) (Table 3). 

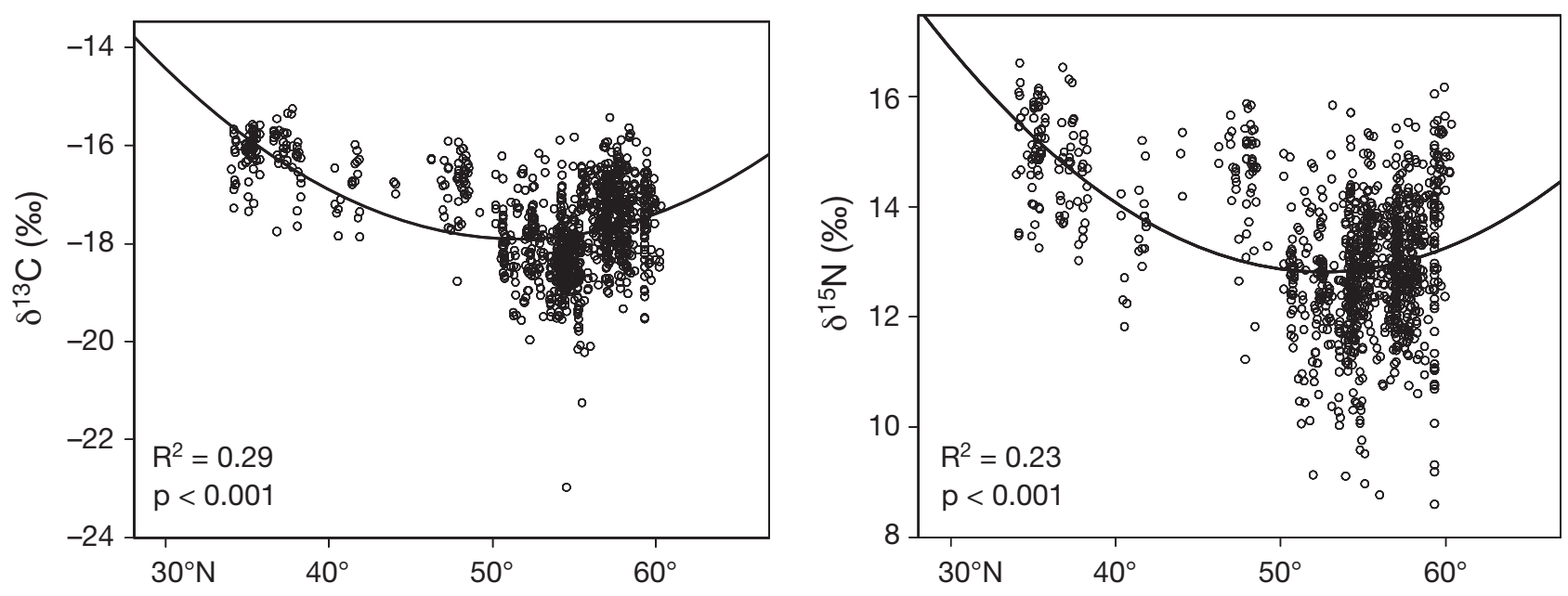

Latitude
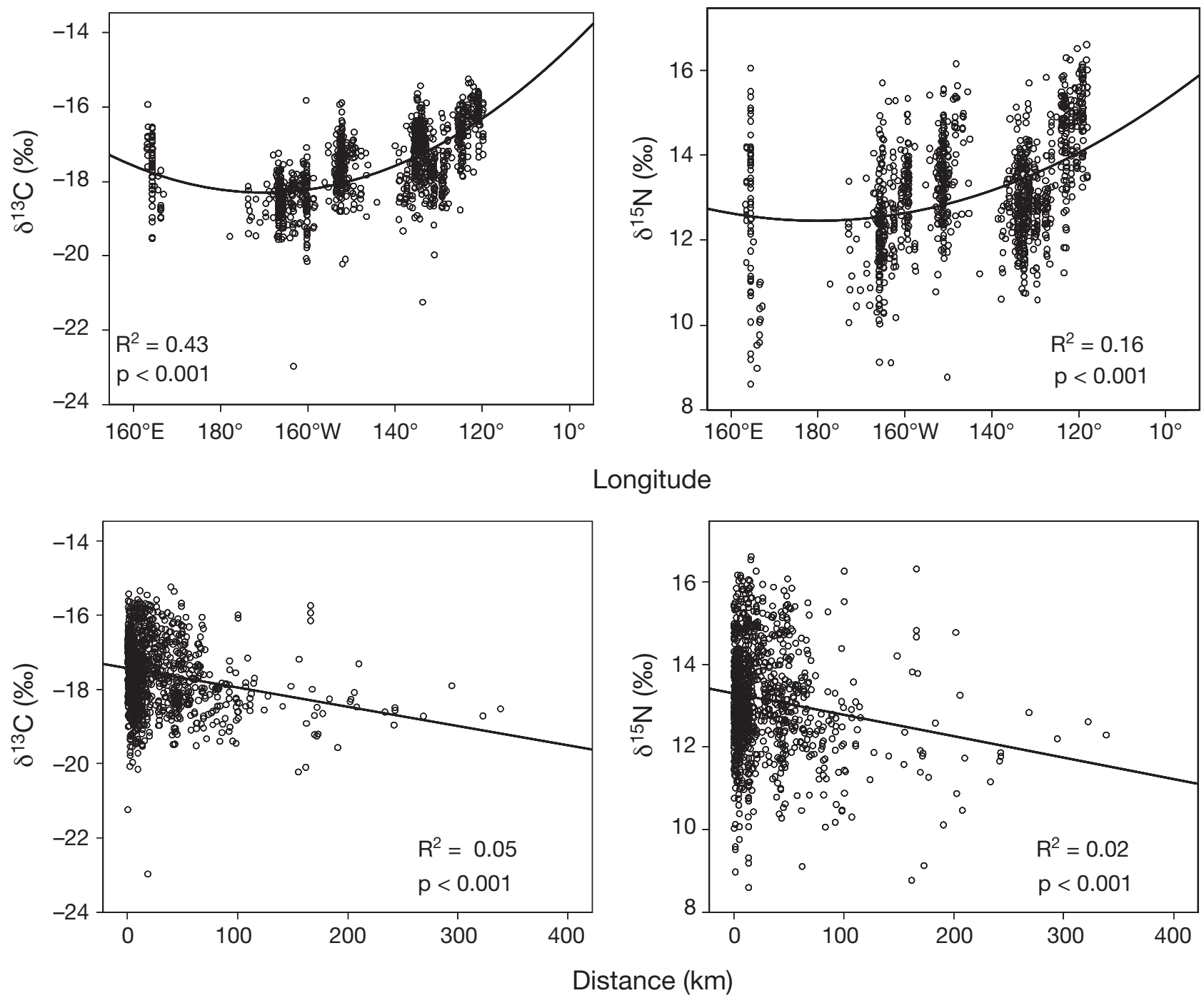

Fig. 2. Megaptera novaeangliae. Relationships between $\delta^{13} \mathrm{C}$ and $\delta^{15} \mathrm{~N}$ of North Pacific humpback whale skin to latitude, longitude and distance from shore $(\mathrm{km})$. Regression results are also shown 
Table 2. Classification tree analysis using $\delta^{13} \mathrm{C}$ and $\delta^{15} \mathrm{~N}$ of humpback whale skin collected from 10 sampling regions as predicting variables. Values shown are the percent of total samples that were assigned to each region. Abbreviations defined in 'Materials and methods: Sample collection'

\begin{tabular}{|c|c|c|c|c|c|c|c|c|c|c|c|c|}
\hline \multirow{2}{*}{$\begin{array}{l}\text { Known } \\
\text { sampling } \\
\text { region }\end{array}$} & \multirow[b]{2}{*}{ RUS } & \multirow[b]{2}{*}{ BER } & \multirow[b]{2}{*}{ WAI } & \multirow[b]{2}{*}{ EAI } & \multirow[b]{2}{*}{ WGOA } & \multicolumn{3}{|c|}{ Predicted sampling region } & \multirow[b]{2}{*}{ WASBC } & \multirow[b]{2}{*}{ CAOR } & \multirow[b]{2}{*}{ Total } & \multirow[b]{2}{*}{$\begin{array}{c}\% \\
\text { Correct }\end{array}$} \\
\hline & & & & & & NGOA & SEAK & $\mathrm{NBC}$ & & & & \\
\hline RUS & 18 & 2 & 0 & 0 & 0 & 20 & 24 & 3 & 0 & 0 & 67 & 27 \\
\hline BER & 12 & 77 & 0 & 0 & 6 & 19 & 3 & 5 & 0 & 0 & 122 & 63 \\
\hline WAI & 8 & 5 & 0 & 0 & 0 & 1 & 0 & 0 & 0 & 0 & 14 & 0 \\
\hline EAI & 10 & 34 & 0 & 0 & 0 & 9 & 1 & 2 & 0 & 0 & 56 & 0 \\
\hline WGOA & 0 & 39 & 0 & 0 & 23 & 33 & 2 & 6 & 0 & 1 & 104 & 22 \\
\hline NGOA & 3 & 23 & 0 & 0 & 3 & 107 & 31 & 18 & 12 & 1 & 198 & 54 \\
\hline SEAK & 2 & 29 & 0 & 0 & 0 & 34 & 145 & 12 & 5 & 0 & 227 & 64 \\
\hline NBC & 5 & 40 & 0 & 0 & 0 & 31 & 23 & 30 & 6 & 0 & 135 & 22 \\
\hline WASBC & 0 & 1 & 0 & 0 & 0 & 9 & 6 & 1 & 24 & 12 & 53 & 45 \\
\hline CAOR & 0 & 0 & 0 & 0 & 0 & 10 & 36 & 0 & 13 & 69 & 128 & 54 \\
\hline & & & & & & & & & & & Overall & 45 \\
\hline
\end{tabular}

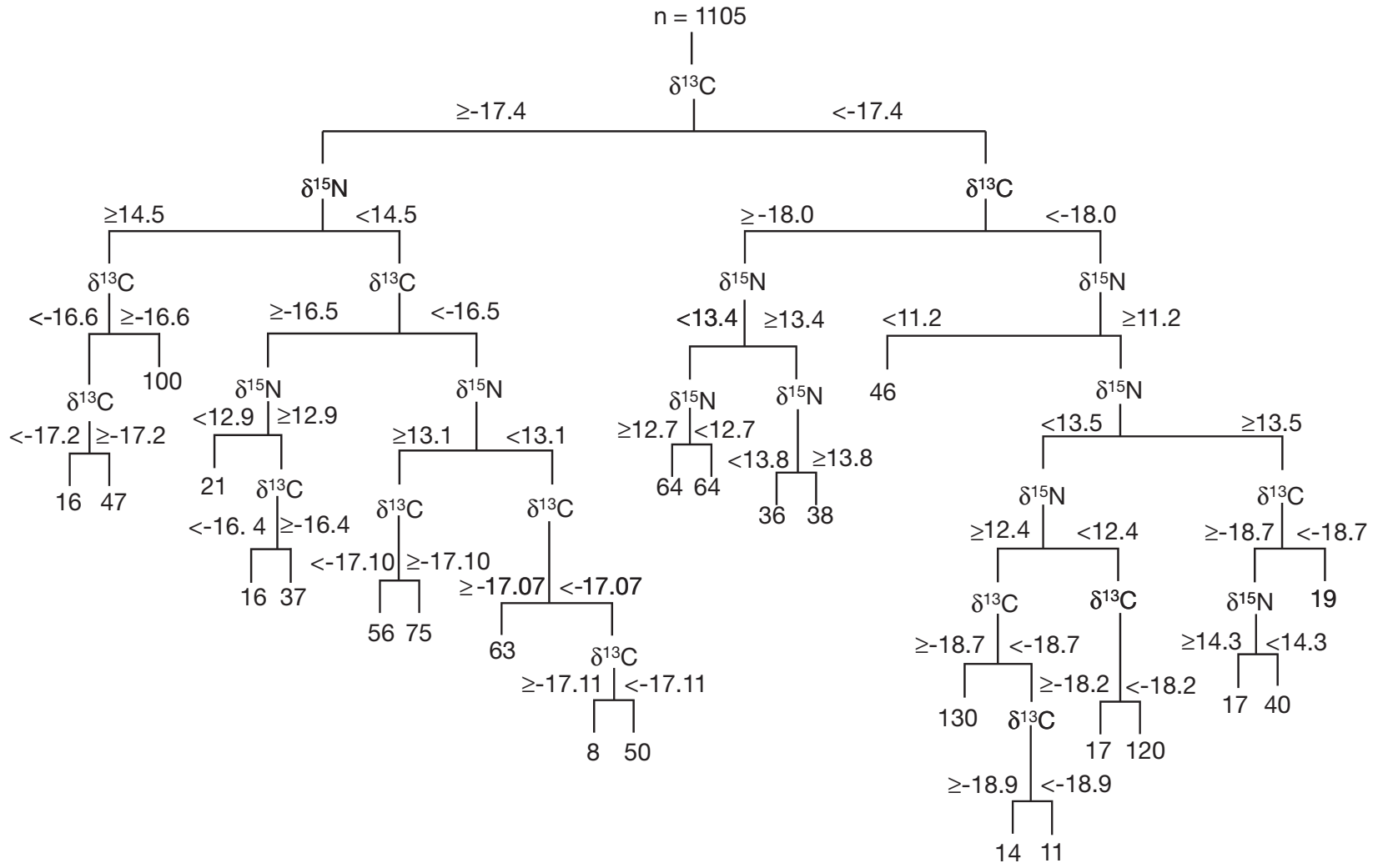

Fig. 3. Megaptera novaeangliae. Final classification tree for feeding groups using $\delta^{13} \mathrm{C}$ and $\delta^{15} \mathrm{~N}$ from humpback whale skin. Rationale for each split is indicated by $\delta$ values. Numbers at the terminal nodes indicate the final number of samples assigned to that node

Random assignment correctly predicted feeding group membership $17 \%$ of the time on average, with distribution among feeding groups as 16, 12, 21, 18, 26 and $7 \%$ for COW, NBC, SEAK, NGOA, CENT and WEST respectively. Thus, the classification tree for feeding groups performed 3.4 times better, on average, than random assignment by chance alone with a range of 1.5 to 4.8 .

\section{DISCUSSION}

\section{Geographic variability}

Stable isotope ratios of carbon and nitrogen can be used to distinguish distinct feeding groups of humpback whales. Both $\delta^{13} \mathrm{C}$ and $\delta^{15} \mathrm{~N}$ varied significantly with respect to latitude, longitude and distance from 
Table 3. Results of classification tree analysis using $\delta^{13} \mathrm{C}$ and $\delta^{15} \mathrm{~N}$ of humpback whale skin collected from 6 feeding groups as predicting variables. Feeding groups were formed based on ANOVA and misclassification of sampling regions in preliminary classification tree analysis. NGOA: northern Gulf of Alaska; SEAK: southeastern Alaska; NBC: northern British Columbia; combined feeding groups - WEST: western region; CENT: central region; COW: California, Oregon, Washington and southern British Columbia

\begin{tabular}{|c|c|c|c|c|c|c|c|c|}
\hline \multirow{2}{*}{$\begin{array}{l}\text { Known } \\
\text { feeding } \\
\text { group }\end{array}$} & \multirow[b]{2}{*}{ WEST } & \multirow[b]{2}{*}{ CENT } & \multicolumn{4}{|c|}{ — Predicted feeding group } & \multirow[b]{2}{*}{ Total } & \multirow[b]{2}{*}{$\begin{array}{c}\% \\
\text { Correct }\end{array}$} \\
\hline & & & NGOA & SEAK & NBC & COW & & \\
\hline WEST & 28 & 14 & 12 & 26 & 0 & 1 & 81 & 35 \\
\hline CENT & 19 & 218 & 17 & 15 & 12 & 1 & 282 & 77 \\
\hline NGOA & 1 & 50 & 66 & 47 & 16 & 18 & 198 & 33 \\
\hline SEAK & 3 & 28 & 24 & 150 & 8 & 14 & 227 & 66 \\
\hline NBC & 2 & 44 & 21 & 35 & 25 & 8 & 135 & 19 \\
\hline \multirow[t]{2}{*}{ COW } & 1 & 3 & 18 & 14 & 3 & 142 & 181 & 78 \\
\hline & & & & & & & Overall & 57 \\
\hline
\end{tabular}

effects in the CENT sampling regions, such as freshwater influence or anthropogenic sources of carbon. Another explanation is that latitude was not the only factor determining the distribution of $\delta^{13} \mathrm{C}$ in North Pacific humpback whales.

Other known $\delta^{13} \mathrm{C}$ gradients may explain the spatial variation in stable carbon isotope ratios, which are generally lower in pelagic (offshore) food webs than in benthic (nearshore) food webs (McConnaughey \& McRoy 1979, Hobson 1993, Burton \& Koch 1999). Most samples in SEAK and NGOA were collected in near-shore habitats and had higher $\delta^{13} \mathrm{C}$ values than could shore of sample collection. Numerous previous studies have explored latitudinal gradients in $\delta^{13} \mathrm{C}$, and most have found that $\delta^{13} \mathrm{C}$ is higher at mid latitudes than at higher latitudes (Rau et al. 1982, Goericke \& Fry 1994). Results presented here are somewhat contrary. Values of $\delta^{13} \mathrm{C}$ at the highest latitudes (NGOA, SEAK and RUS) were not the most depleted as would be expected, indicating a quadratic, not linear, relationship between latitude and carbon stable isotope ratios (Fig. 4). The mean $\delta^{13} \mathrm{C}$ values of humpback whale skin from NGOA were similar to those from previous studies for marine mammals, but values from CENT seemed to be more depleted in comparison (Hobson et al. 1997, Kurle \& Worthy 2001, 2002). Thus, the deviation in the expected linear pattern may be driven by

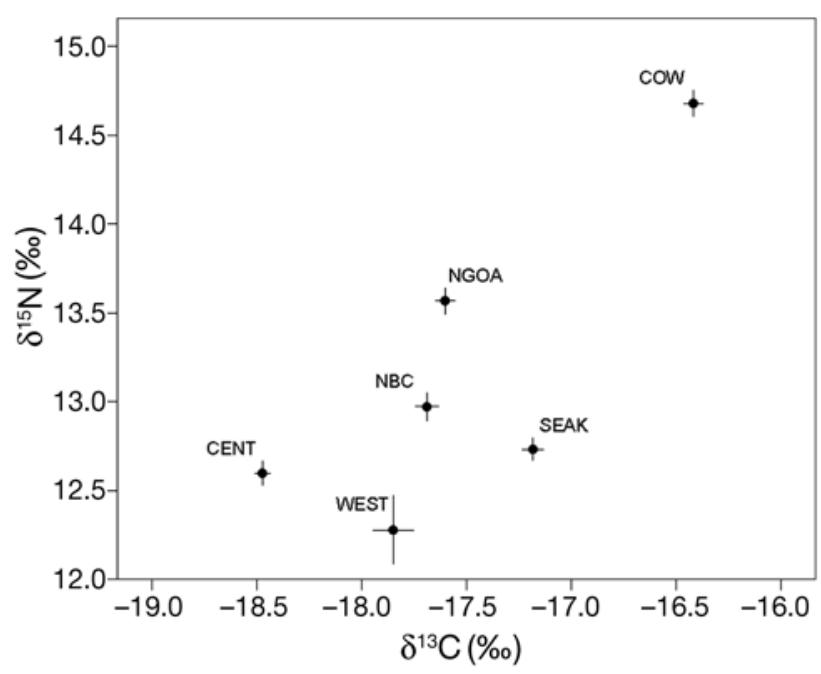

Fig. 4. Megaptera novaeangliae. Mean values $( \pm \mathrm{SE})$ of $\delta^{15} \mathrm{~N}$ and $\delta^{13} \mathrm{C}$ for each of the 6 feeding groups. Combined feeding groups (see 'Results: Classification') — WEST: western region; CENT: central region; COW: California, Oregon, and Washingtion and southern British Columbia. Further abbreviations in 'Materials and methods: Sample collection' be explained by latitude alone. Similarly, a significant portion of NBC and CENT samples were collected either off the continental shelf or very near the edge and were more depleted than those collected on the shelf. Depletion in samples collected in close proximity to or off the shelf edge may exhibit stable carbon isotope ratios indicative of pelagic food webs. Thus, distance from the shelf edge, rather than distance from shore, may have a stronger influence, Regardless, it is clear that the stable carbon isotope ratio of North Pacific humpback whale skin was probably determined by the interplay between latitudinal, benthic versus pelagic and, perhaps most importantly, longitudinal food web gradients (see below).

The $\delta^{15} \mathrm{~N}$ values of humpback whale skin varied quadratically with increasing latitude as well (Fig. 2). Wada \& Hattori (1991) suggested latitudinal gradients in the $\delta^{15} \mathrm{~N}$ values of phytoplankton were the result of low concentration of ammonia and nitrite in tropical areas, but Rubenstein \& Hobson (2004) stated that the reasons for ${ }^{15} \mathrm{~N}$ enrichment with increasing latitude were unclear. Differences in nitrogen signatures may also be attributed to trophic position, with $\delta^{15} \mathrm{~N}$ increasing between 3 and $4 \%$ with each trophic level (Peterson \& Fry 1987). Humpback whales are classified as generalists, foraging on both fish and zooplankton (Nemoto \& Kasuya 1965, Nemoto 1973, Perry et al. 1999), but regional differences in prey choice may affect relative trophic positions of feeding groups. However, the cause of differences in $\delta^{15} \mathrm{~N}$ cannot be determined without first establishing the $\delta^{15} \mathrm{~N}$ value at the base of regional food webs (Post 2002). Initial review of $\delta^{15} \mathrm{~N}$ from primary consumers shows differences in the stable nitrogen isotope ratios near California (ratio $=8.8$; Miller 2006), Kodiak, Alaska (9.1; Hirons 2001) and the Bering Sea (8.1; Hirons 2001). Differences in $\delta^{15} \mathrm{~N}$ at the level of primary consumer suggest that humpback whales in the NGOA and 
COW feeding groups may feed at higher trophic levels (primarily on fish), while CENT may be feeding at a lower level (primarily on zooplankton; Lesage et al. 2001, Das et al. 2003). Additional data on $\delta^{15} \mathrm{~N}$ values at the base of food webs for each of the feeding groups will help to further explore differences in trophic positions.

The quadratic relationships between both $\delta^{13} \mathrm{C}$ and $\delta^{15} \mathrm{~N}$ and longitude contradicted previously observed relationships. Previous studies found no longitudinal effect on $\delta^{15} \mathrm{~N}$, but a strong increase in $\delta^{13} \mathrm{C}$ from east to west (Saupe et al. 1989, Schell et al. 1998, Knoche et al. 2007). The large size of our study area may have contributed to this difference. Increasing stable carbon isotope ratios from east to west have been attributed to freshwater inputs and areas of lower salinity within study areas that are relatively small in scale when compared with the entire North Pacific Ocean (Naidu et al. 1993, Schell et al. 1998). In such studies, sources of freshwater input may be identified as a single river basin, but given the breadth of our study area it is not possible to identify all of the sources that may be driving the observed pattern. Regardless of cause the isotopic ratio of carbon, and to a lesser extent nitrogen, in humpback whale skin varied significantly with longitude.

\section{Individual variation}

The stable isotope ratios of twice-sampled animals can be predicted based on known patterns of stable isotope ratios in foraging animals. If sequential sampling of an individual occurs within the same sampling region, isotopic signatures, carbon in particular, should remain relatively constant. If the animal moves to a different feeding area between sampling events, however, changes in the stable isotope ratios should be detectable. Exploration of twice-sampled humpback whales in this study supports both predictions. When both sampling events occurred in the same sampling region, $\delta^{13} \mathrm{C}$ and $\delta^{15} \mathrm{~N}$ were not significantly different, regardless of whether sampling events occurred in the same or sequential years. In contrast, whales sampled in different feeding regions showed significant differences in these ratios. These results lend considerable support to the use of stable isotope ratios as descriptors of foraging locations.

\section{Classification}

Classification trees represent a modern statistical technique well suited for modeling ecological data. Assignment through a classification tree does not require assumption of parameter distribution and is capable of combining both discrete and continuous data (Hobson \& Wassenaar 2008). Further, model output is hierarchical, graphical and based on logical 'if-then' conditions (De'ath \& Fabricius 2000, Spruill et al. 2002, StatSoft 2007). Other methods of classification commonly used in isotopic studies of origin, such as discriminant function analysis and regression, require linear relationships and can therefore be limiting. Relationships between stable isotope ratios and external factors explored in this study were best explained by nonlinear regressions. As a result, linear methods of classification, including discriminant function analysis, may be less suited for this data set.

Classification tree analysis was able to assign $57 \%$ of the humpback whale tissue samples to the correct feeding group in the best performing model (Table 3 ). In this tree, groups were classified using both $\delta^{13} \mathrm{C}$ and $\delta^{15} \mathrm{~N}$. The best model correctly classified all 6 feeding groups over 3 times more often, on average, than random assignment and nearly 5 times more often for 2 of the groups. Classification was lowest for NBC, NGOA and WEST, with misclassifications occurring at rates $>50 \%$.

There are a number of potential reasons behind misclassifications. First, similarities in the sampling position between regions may result in misclassifications due to latitudinal or longitudinal effects on stable isotope ratios. Latitudinal similarities may explain the high classification of NBC samples to CENT since the mean sampling latitude differed by only $2^{\circ}$, on average, between these 2 groups.

Additional misclassification could be explained if a feeding group does not truly represent a distinct feeding destination for North Pacific humpback whales, but rather a transitional area for animals en route to other feeding grounds. Wide distribution of misclassification to other feeding groups, such as the distribution of misclassifications for NBC, may indicate a transitional area. Also, boundaries between feeding groups may not be exactly as described. For example, the boundary between CENT and NGOA may actually lie within the WGOA and samples from this region should be divided amongst these feeding groups rather than assigned exclusively to WEST.

Finally, small sample size or high variability may account for misclassifications. The RUS and WAI sampling regions, which together comprised the WEST feeding group, showed some of the highest regional variability in stable isotope ratios and the lowest sample sizes, which may have contributed to the large misclassification rates for WEST. Whether this high variability was merely the result of smaller sample size is unclear, but increased future sampling efforts in these regions may help elucidate the potential influences on 
isotopic variability to help improve classification for this feeding group.

The time frame of the diet estimated from stable isotope ratios depends on tissue turnover rates. The turnover rate of humpback whale skin has never been measured, but Todd (1997) estimated a turnover rate of approximately 7 to $14 \mathrm{~d}$. However, turnover was not likely to play a significant role in the analyses presented here. The turnover rate of humpback whale skin should not influence stable isotope ratios if animals are using the same feeding groups throughout the feeding season, which was a primary assumption of this study.

\section{CONCLUSIONS}

Overall, ratios of carbon and nitrogen stable isotopes in humpback whale skin showed considerable promise for distinguishing unique feeding groups of North Pacific humpback whales. The ability of a multipleisotope classification tree to determine feeding location has far-reaching implications. Beyond defining distinct feeding groups, geographic differences in stable isotope ratios of both humpback whales and their potential prey can be used to explore the foraging ecology and prey use within regional food webs. The ability to describe differences in diets may contribute to the understanding of prey selection and specialized foraging behaviors between and among regions. Perhaps more importantly, the classification model may be able to identify the feeding destination of humpback whales while they are fasting on their breeding grounds. Successful application of this model will provide a new method of describing the migratory movements of humpback whales without the need for a resighting or resampling event. Using stable isotopes to classify feeding location and explore regional diets can help elucidate how choice of prey or foraging location dictates animal health and, in turn, contributes to the degree of success in mating and calving on breeding grounds. This technique would clearly be applicable to the numerous migratory populations of species for which the effects of foraging are carried over to breeding grounds.

Acknowledgements. We are particularly grateful to all member of the SPLASH steering committee for their generosity with humpback whale skin samples and general support of this project. We also thank D. Jenkins, A. Hirons and R. Foy for technical advice, statistical analysis and manuscript suggestions. The staff of the genetics lab at the Southwest Fisheries Science Center, in particular G. Serra-Valente, K. Robertson and $\mathrm{C}$. Leduc, was tremendously helpful with many aspects of sample retrieval and data sharing. A. Fisk, C. Clark and J. Tompson provided field and lab assistance. The
National Fish and Wildlife Foundation provided funding for sex analysis, which was conducted by C. S. Baker and D. Steel at Oregon State University. Support for stable isotope analysis was provided by NOAA grant no. NA16FX1270 awarded to K.M.W. Additional funding was provided by the University of Central Florida (UCF) Board of Trustee's Doctoral Fellowship and operating funds from UCF to G.A.J.W.

\section{LITERATURE CITED}

Baduini CL, Hunt GL, Pinchuk AI, Coyle KO (2006) Patterns in diet reveal foraging site fidelity of short-tailed shearwaters in the southeastern Bering Sea. Mar Ecol Prog Ser 320:279-292

Baker CS, Medrano-Gonzalez L, Calambokidis J, Perry A and others (1998) Population structure of nuclear and mitochondrial DNA variation among humpback whales in the North Pacific. Mol Ecol 7:695-707

Baraff LS, Clapham PJ, Mattila DK, Bowman RS (1991) Feeding behaviour of a humpback whale in low latitude waters. Mar Mamm Sci 7:197-202

Born EW, Outridge P, Riget FF, Hobson KA, Dietz R, Oien N, Haug T (2003) Population substructure of North Atlantic minke whales (Balaenoptera acutorostrata) inferred from regional variation of elemental and stable isotopic signatures in tissues. J Mar Syst 43:1-17

Boutton TW (1991) Stable carbon isotope ratios of natural materials. II. Atmospheric, terrestrial, marine and freshwater environments. In: Coleman DC, Fry B (eds) Carbon isotope techniques. Academic Press, San Diego, CA, p 173-186

Breiman LJ, Friedman JH, Olshen RA, Stone CJ (1984) Classification and regression trees. Chapman \& Hall/CRC, New York

Burnham KP, Anderson DR (2002) Model selection and multimodel inference: a practical information theoretic approach. Springer, New York

Burton RK, Koch PL (1999) Isotopic tracking of foraging and long-distance migration in northeastern Pacific pinnipeds. Oecologia 119:578-585

Caccamise DF, Reed LM, Castelli PM, Wainright S, Nichols TC (2000) Distinguishing migratory and resident Canada geese using stable isotope analysis. J Wildl Manag 64: 1084-1091

> Calambokidis J, Steiger GH, Evenson JR, Flynn KR and others (1996) Interchange and isolation of humpback whales off California and other North Pacific feeding grounds. Mar Mamm Sci 12:215-226

Calambokidis J, Steiger GH, Straley JM, Herman LM and others (2001) Movements and population structure of humpback whales in the North Pacific. Mar Mamm Sci 17:769-794

Calambokidis J, Falcone EA, Quinn TJ II, Burdin AM and others (2008) SPLASH: Structure of populations, levels of abundance and status of humpback whales in the North Pacific. Final report for contract AB133F-03-RP-00078, U.S. Dept of Commerce Western Administrative Center, Seattle, WA

Caut S, Guirlet E, Angulo E, Das K, Girondot M (2008) Isotope analysis reveals foraging area dichotomy for Atlantic leatherback turtles. PLoS One 3:e1845

- Das K, Lepoint G, Leroy Y, Bouquegneau JM (2003) Marine mammals from the southern North Sea: feeding ecology data from $\delta^{13} \mathrm{C}$ and $\delta^{15} \mathrm{~N}$ measurements. Mar Ecol Prog Ser 263:287-298

Dawbin WH (1966) The seasonal migratory cycle of humpback whales. In: Norris KS (ed) Whales, dolphins, and 
porpoises. University of California Press, Berkley, CA, p $145-170$

De'ath G, Fabricius K (2000) Classification and regression trees: a powerful yet simple technique for ecological data analysis. Ecology 81:3178-3192

Dobush GR, Ankney CD, Krementz DG (1985) The effect of apparatus, extraction time, and solvent type on lipid extractions of snow geese. Can J Zool 63:1917-1920

Farmer A, Rye R, Landis G, Bern C, Kester C, Ridley I (2003) Tracing the pathways of neotropical migratory shorebirds using stable isotopes: a pilot study. Isotopes Environ Health Stud 39:169-177

Field A (2005) Discovering statistics using SPSS. Sage Publications, London

Fry B (1981) Natural stable carbon isotope tag traces Texas shrimp migrations. Fish Bull 79:337-345

Goericke R, Fry B (1994) Variations of marine plankton $\delta^{13} \mathrm{C}$ with latitude, temperature, and dissolved $\mathrm{CO}_{2}$ in the world ocean. Global Biogeochem Cycles 8:85-90

Hebert CE, Wassenaar LI (2005a) Feather stable isotopes in western North American waterfowl: spatial patterns, underlying factors, and management applications. Wildl Soc Bull 33:92-102

Hebert CE, Wassenaar LI (2005b) Stable isotopes provide evidence for poor northern pintail production on the Canadian Prairies. J Wildl Manag 69:101-109

Hirons AC (2001) Trophic dynamics of pinnipeds in Alaska using stable carbon and nitrogen isotope ratios. $\mathrm{PhD}$ dissertation, University of Alaska, Fairbanks

Hobson KA (1993) Trophic relationships among high arctic seabirds: insights from tissue-dependent stable-isotope models. Mar Ecol Prog Ser 95:7-18

Hobson KA (1999) Tracing origins and migration of wildlife using stable isotopes: a review. Oecologia 120:314-326

Hobson KA (2006) Establishing migratory connectivity and seasonal interactions using stable isotopes. J Ornithol 147: $52-53$

Hobson K, Wassenaar LI (2008) Tracking animal migration with stable isotopes. Academic Press, London

Hobson KA, Piatt JF, Pitocchelli J (1994) Using stable isotopes to determine seabird trophic relationships. J Anim Ecol 63: 786-798

Hobson KA, Sease JL, Merrick RL, Piatt JF (1997) Investigating trophic relationships of pinnipeds in Alaska and Washington using stable isotope ratios of nitrogen and carbon. Mar Mamm Sci 13:114-132

Ivashin MV, Rovnin AA (1967) Some results of Soviet whale marking in the waters of the North Pacific. Norsk Hvalfangst-Tidende 56:123-135

Kelly JF (2000) Stable isotopes of carbon and nitrogen in the study of avian and mammalian trophic ecology. Can J Zool 78:1-27

Kennedy BP, Chamberlain CP, Blum JD, Nislow KH, Folt CL (2005) Comparing naturally occurring stable isotopes of nitrogen, carbon, and strontium as markers for the rearing locations of Atlantic salmon (Salmo salar). Can J Fish Aquat Sci 62:48-57

Knoche MJ, Powell AN, Quakenbush LT, Wooller MJ, Phillips LM (2007) Further evidence for site fidelity to wing molt locations by king eiders: integrating stable isotope analyses and satellite telemetry. Waterbirds 30:52-57

Kurle CM, Worthy GAJ (2001) Stable isotope assessment of temporal and geographic differences in feeding ecology of northern fur seals (Callorhinus ursinus) and their prey. Oecologia 126:254-265

Kurle CM, Worthy GAJ (2002) Stable nitrogen and carbon isotope ratios in multiple tissues of the northern fur seal
Callorhinus ursinus: implications for dietary and migratory reconstructions. Mar Ecol Prog Ser 236:289-300

Laerm J, Wenzel F, Craddock JE, Weinand D and others (1997) New prey species for northwestern Atlantic humpback whales. Mar Mamm Sci 13:705-711

Lesage V, Hammill MO, Kovacs KM (2001) Marine mammals and the community structure of the Estuary and Gulf of St Lawrence, Canada: evidence from stable isotope analysis. Mar Ecol Prog Ser 210:203-221

Lockyer C (1981) Growth and energy budgets of large baleen whales from the southern hemisphere. FAO Fish Ser 5: $379-487$

Marcoux M, Whitehead H, Rendell L (2007) Sperm whale feeding variation by location, year, social group and clan: evidence from stable isotopes. Mar Ecol Prog Ser 333: 309-314

McConnaughey T, McRoy CP (1979) Food web structure and the fractionation of carbon isotopes in the Bering Sea. Mar Biol 53:257-262

Miller TW (2006) Trophic dynamics of marine nekton and zooplankton in the Northern California Pelagic Ecosystem. PhD dissertation, Oregon State University, Corvallis

> Minagawa M, Wada E (1984) Stepwise enrichment of ${ }^{15} \mathrm{~N}$ along food chains: further evidence and the relation between $\delta^{15} \mathrm{~N}$ and animal age. Geochim Cosmochim Acta 48:1135-1140

Moran MD (2003) Arguments for rejecting the sequential Bonferroni in ecological studies. Oikos 100:403-405

> Naidu AS, Scanlon RS, Feder HM, Goering JJ and others (1993) Stable organic carbon isotopes in sediments of the north Bering-south Chukchi seas, Alaskan-Soviet Arctic shelf. Cont Shelf Res 13:669-691

Nemoto T (1973) Feeding pattern of baleen whales in the ocean. In: Steele JH (ed) Marine food chains. Oliver and Boyd, Edinburgh, p 241-252

Nemoto T, Kasuya T (1965) Foods of baleen whales in the Gulf of Alaska of the North Pacific. Sci Rep Whales Res Inst 19:45-51

Nishiwaki M (1966) Distribution and migration of the larger cetaceans in the North Pacific as shown by Japanese whaling records. In: Norris KS (ed) Whales, dolphins, and porpoises. University of California Press, Berkeley, CA, p 172-191

Perry SL, DeMaster DP, Silber GK (1999) The great whales: history and status of six species listed as endangered under the U.S. Endangered Species Act of 1973. Mar Fish Rev 61(1 Spec Issue):1-23, 68-74

> Peterson BJ, Fry B (1987) Stable isotopes in ecosystem studies. Annu Rev Ecol Syst 18:293-320

Post DM (2002) Using stable isotopes to estimate trophic position: models, methods, and assumptions. Ecology 83: 703-720

Rau GH, Sweeney RE, Kaplan IR (1982) Plankton ${ }^{13} \mathrm{C}:{ }^{12} \mathrm{C}$ ratio changes with latitude: differences between northern and southern oceans. Deep-Sea Res I Oceanogr Res Pap 29: 1035-1039

> Rocque DA, Ben-David M, Barry RP, Winker K (2006) Assigning birds to wintering and breeding grounds using stable isotopes: lessons from two feather generations among three intercontinental migrants. J Ornithol 147: 395-404

Rubenstein DR, Hobson KA (2004) From birds to butterflies: animal movement patterns and stable isotopes. Trends Ecol Evol 19:256-263

Saupe SM, Schell DM, Griffiths WB (1989) Carbon-isotope ratio gradients in western Arctic zooplankton. Mar Biol 103: $427-432$ 
Schell DM, Barnett BA, Vinette KA (1998) Carbon and nitrogen isotope ratios in zooplankton of the Bering, Chukchi and Beaufort seas. Mar Ecol Prog Ser 162:11-23

Spruill TB, Showers WJ, Howe SS (2002) Application of classification-trees methods to identify nitrate sources in ground water. J Environ Qual 31:1538-1549

StatSoft (2007) StatSoft I. Electronic statistics text book. StatSoft, Tulsa, OK. www.statsoft.com/textbook/stathome. html (accessed 15 August 2008)

Straley JM (1994) Seasonal characteristics of humpback whales (Megaptera novaeangliae) in southeastern Alaska. MS thesis, University of Alaska, Fairbanks, AK

Szymanski ML, Afton AD, Hobson KA (2007) Use of stable isotope methodology to determine natal origins of mallards at a fine scale within the upper Midwest. J Wildl Manag 71:1317-1324

Todd SK (1997) Dietary patterns of humpback whales (Megaptera novaeangliae) in the Northwest Atlantic: evidence from ${ }^{13} \mathrm{C}$ and ${ }^{15} \mathrm{~N}$ stable isotopes. $\mathrm{PhD}$ thesis, Memorial University of Newfoundland, St. John's

Editorial responsibility: Yves Cherel,

Villiers-en-Bois, France
Todd S, Ostrom P, Lien J, Abrajano J (1997) Use of biopsy samples of humpback whale (Megaptera novaeangliae) skin for stable isotope $\left(\delta^{13} \mathrm{C}\right)$ determination. J Northwest Atl Fish Sci 22:71-76

Wada E, Hattori A (1991) Nitrogen from the sea: forms, abundances and rate processes. CRC Press, Boca Raton, FL

Waite JM, Dahlheim ME, Hobbs RC, Mizroch SA and others (1999) Evidence of a feeding aggregation of humpback whales (Megaptera novaeangliae) around Kodiak Island, Alaska. Mar Mamm Sci 15:210-220

Witteveen BH, Straley JM, von Ziegesar O, Steel D, Baker CS (2004) Abundance and mtDNA differentiation of humpback whales (Megaptera novaeangliae) in the Shumagin Islands, Alaska. Can J Zool 82:1352-1359

Wunder MB, Kester CL, Knopf FL, Rye RO (2005) A test of geographic assignment using isotope tracers in feathers of known origin. Oecologia 144:607-617

Zerbini AN, Waite JM, Laake JL, Wade PR (2006) Abundance, trends and distribution of baleen whales off Western Alaska and the central Aleutian Islands. Deep-Sea Res 53:1772-1790

Submitted: May 7, 2008; Accepted: December 19, 2008

Proofs received from author(s): March 16, 2009 